it free. Parts II and III will include in full all specialized papers on "Power Engineering" and "Communication Engineering" respectively, thus giving recognition to the two main fields of electrical engineering activity. For these two parts members must apply specially and a small additional charge is to be made; Part II will appear in alternate months and Part III quarterly. Free advance copies of papers accepted for reading at meetings will still be available. Part III incorporates the Proceedings of the Wireless Section, and also includes papers on telegraphy and telephony; these are comparatively few and will probably be of interest to members of the Section. The new feature which has been introduced into Part I, of giving abstracts of all papers which are published in Parts II and III, will, it is felt, be of considerable value to all members.

\section{Earthquake in Cyprus}

ON January 20 at about 5.40 a.m. local time, an earthquake of considerable severity occurred, shaking the whole island of Cyprus for about half a minute. The epicentre of the earthquake was probably in the neighbourhood of the port of Famagusta, where forty-four houses are reported to have collapsed and other buildings damaged. The Cathedral of St. Nicholas was slightly damaged. Seven people are reported injured. At Nicosia some houses and one or two churches were cracked by the earthquake, though here no casualties are mentioned in reports so far received.

\section{The Night Sky in February}

DURING this month, the night shortens by nearly two hours in the latitude of London. The moon is full on February 12 and new on February 26. Lunar conjunctions with Jupiter and Saturn occur on February 3 at $19 \mathrm{~h}$. and $2 \mathrm{Ih}$. U.T. respectively. The moon is in conjunction with Mars on February 21 at $3 \mathrm{~h}$, the moon rising that morning at $3 \mathrm{~h}$. $47 \mathrm{~m}$. at Greenwich. Jupiter and Saturn still continue in close company, just within the southern limit of the constellation Aries, and they reach conjunction with one another on February 20 at $19 \mathrm{~h}$. On that day they come to the southern meridian at Greenwich at $16 \mathrm{~h}$. $30 \cdot 4 \mathrm{~m}$. Thereafter, Jupiter draws away eastwards from Saturn. The distant planet, Uranus (seen as a 6 th magnitude star but with a true disk $3 \frac{1}{2}$ in diameter), is just within the western border of Taurus, in a region south-preceding the Pleiades and devoid of stars as bright as the 6th magnitude. At the time of the planet's discovery in 1781 by Sir William Herschel, Uranus was in the neighbouring constellation of Gemini. By using a large range of powers (from 230 to 2000), Herschel was convinced from a telescopic examination alone that the object, called by him at first a 'comet', was definitely not one of the fixed stars. In mid-February at about 20h., Orion comes to the southern meridian. Light changes of the variable star Algol ( $\beta$ Persei), may be observed about $1 \frac{1}{2}$ hours before and after the following times : February 9 d. $4 \cdot 9 \mathrm{~h} .: 12 \mathrm{~d} .1 \cdot 7 \mathrm{~h} .: 14 \mathrm{~d} .22 \cdot 5 \mathrm{~h}$. and 17d. 19.4h. U.T. (add 1 h. to reckon in Summer Time).

\section{Announcements}

THE Council of the Geological Society has made the following awards: Wollaston Medal to Dr. A. L. Day, of the Geophysical Laboratory, Washington, D.C.; Murchison Medal to Dr. Murray Macgregor, of H.M. Geological Survey (Scotland); Lyell Medal to Mr. Ernest Sheppard Pinfold; Bigsby Medal to Dr. C. J. Stubblefield, of H.M. Geological Survey; Wollaston Fund to Dr. K. P. Oakley, of the British Museum (Natural History); Murchison Fund to Dr. John Weir, of the University of Glasgow ; a moiety of the Lyell Fund to Mr. W. Eltringham; another moiety of the Lyell Fund to Dr. F. S. Wallis, of the Bristol Museum and Art Gallery.

The Buchan Prize for 1941 of the Royal Meteorological Society has been awarded to Mr. H. L. Wright for papers contributed to the Quarterly Journal of the Society during 1935 -39.

THE Chadwick Trustees recently offered two prizes of $£ 100$ and $£ 50$ for essays on the construction and management of air raid shelters, with special reference to ventilation, heating, sanitation and the provision. of sleeping accommodation. The prizes have been awarded as follows: $£ 100$ to Mr. Phillip O. Reece and Dr. S. L. Wright, of Wembley, Middlesex ; $£ 50$ to Mr. Jocelyn F. Adburgham, of Victoria Street, Westminster, S.W.1.

A Neurologicar Section has recently been added to the Caroline Medical Institute in Stockholm, the principal medical school of Sweden, under the direction of Prof. Ragnan Granit, an international authority on electro-physiology.

THE following appointments have recently been made in the Colonial Service: G. L. Bannister, veterinary officer, Tanganyika Territory; J. D. Birkett, veterinary officer, Nigeria; R. W. E. Lewis, veterinary officer, Kenya; I. B. Pullon, veterinary officer, Tanganyika Territory; D. S. Davies (senior agricultural officer, Uganda), deputy director of agriculture, Palestine; H. R. Hosking (botanist), senior botanist, Uganda; J. D. Jameson (agricultural officer), botanist, Uganda.

Mr. T. H. HAwkINs, education officer of the Educational Advisory Board of the British Social Hygiene Council, is resigning his position, in any event for the duration of the War and possibly permanently. The War Emergency Committee of the Educational Advisory Board has been actively promoting both the School Leavers' Courses and the lectures to young people. The education officer is responsible for the administrative work relating to the Educational Advisory Board, the printing and issue of Biology under the direction of the editor, conferences and courses of lectures to teachers on the teaching of biology relating to human problems, and short courses of instructional lectures on the place of sex in life to the 16-23 age group. Applications are invited for this post. Further information can be obtained from the Acting Secretary, the Educational Advisory Board, Tavistock House South, Tavistock Square, W.C.1. 